\title{
Evaluation of the environmental perception of the users over solid residues on the beach of Tamandaré/Brazil
}

Avaliação da percepção ambiental dos usuários sobre resíduos sólidos na praia de Tamandaré/Brasil

Evaluación de la percepción ambiental de los usuarios de los residuos sólidos en la playa de Tamandaré/Brasil

Danubia Rafaela Costa de Miranda ORCID: https://orcid.org/0000-0002-1332-6283 Instituto Tecnológico de Pernambuco, Brazil E-mail: dan-light@hotmail.com.br

Eduardo Paes Barreto

ORCID: https://orcid.org/0000-0001-8301-4878 Instituto de Tecnologia de Pernambuco, Brazil E-mail: edubarretoy@hotmail.com

Hélida Karla Philippini da Silva ORCID: https://orcid.org/0000-0003-1166-0250 Centro Integrado de Saúde Amaury de Medeiros, Brazil E-mail: helidaphilippini@gmail.com

Márcia Cristina de Souza Matos Carneiro

ORCID: https://orcid.org/0000-0001-5397-6646 Instituto Brasileiro de Geografia e Estatística, Brazil E-mail: carmarcia@gmail.com

Carlos Fabricio Assunção da Silva ORCID: https://orcid.org/0000-0001-7009-8996

Universidade Federal de Pernambuco, Brazil E-mail: carlos.assuncao@ufpe.br

\begin{abstract}
The irregular waste disposal is a reality that affects the Brazilian coast. The present study aimed to evaluate the environmental perception of beach users in relation to the production and disposal of solid waste at Tamandaré beach Brazil. It was applied a questionnaire and carried out a quali-quantitative collection that has shown that the impacts mostly pointed out were the damage to the environment, and loss of tourist potential. The main source of dispersion of waste on the Tamandare shore is associated with land-based activities, mainly those arising from tourism. The main causes were the failure in the municipal cleaning system, and beach users lack of awareness on disposing solid waste. It was suggest implementing environmental education programs, infrastructure improvement, and the elaboration of public policies pertinent to the management of solid waste, with the purposes of protection and conservation of natural resources.
\end{abstract}

Keywords: Environmental perception; Solid waste; Coastal environments; Sustainable development.

\section{Resumo}

A disposição irregular de resíduos é uma realidade que atinge o litoral brasileiro. O presente estudo teve como objetivo avaliar a percepção ambiental dos usuários da praia em relação à produção e destinação de resíduos sólidos na praia de Tamandaré - Brasil. Aplicamos um questionário e fizemos coleta quali-quantitativo que mostrou que os impactos mais apontados foram os danos ao meio ambiente e a perda de potencial turístico. A principal fonte de dispersão de resíduos na orla de Tamandaré está associada às atividades terrestres, principalmente as oriundas do turismo. As principais causas foram a falha no sistema de limpeza municipal e a falta de conscientização dos usuários da praia sobre o descarte de resíduos sólidos. Sugerimos a implementação de programas de educação ambiental, melhoria da infraestrutura e elaboração de políticas públicas pertinentes à gestão de resíduos sólidos, com vistas à proteção e conservação dos recursos naturais.

Palavras-chave: Percepção ambiental; Resíduos sólidos; Ambientes costeiros; Desenvolvimento sustentável.

\section{Resumen}

La disposición irregular de residuos es una realidad que afecta a la costa brasileña. El presente estudio tuvo como objetivo evaluar la percepción ambiental de los usuarios de la playa en relación con la producción y disposición de residuos sólidos en la playa Tamandaré - Brasil. Se aplicó un cuestionario cuali-cuantitativo que ha demostrado que los 
impactos más señalados fueron el daño al medio ambiente y la pérdida de potencial turístico. La principal fuente de dispersión de residuos en la costa de Tamandaré está asociada a las actividades realizadas en tierra, principalmente las derivadas del turismo. Las principales causas fueron la falla en el sistema de limpieza municipal y la falta de conciencia de los usuarios de las playas sobre la disposición de los desechos sólidos. Se sugirió implementar programas de educación ambiental, mejoramiento de infraestructura y la elaboración de políticas públicas pertinentes al manejo de residuos sólidos, con fines de protección y conservación de los recursos naturales.

Palabras-clave: Percepción ambiental; Residuos sólidos; Ambientes costeros; Desarrollo sustentable.

\section{Introduction}

Natural resources of coastal and marine areas have scenic values that attract the development of anthropogenic and maritime activities (Liu et al., 2019). The coastal strip of Brazil is 8,698 km long, becoming an instrument of appreciation by users from different places. Due to its complexity, coastal areas have become susceptible to the accumulation of solid waste (Binetti et al., 2020; Pervez et al., 2020), that may come from land routes, from recreational (Pervez et al., 2020; Soto et al., 2021) or marine activities, caused by vessels and the practice of oil and gas exploration (Sanches et al., 2020; Turrell, 2020; Vaneeckhaute \& Fazli, 2020). This waste does not obey geopolitical boundaries, spreading quickly and indiscriminately, only depending on the conjunction of favorable oceanographic conditions, and it can reach even the most unlikely places, such as deserted beaches, ocean islands or coastal reefs (Prevenios et al., 2018; Mantelatto et al., 2020; Rodríguez et al., 2020). The presence of marine residues, mostly resulting from anthropic activities, is responsible for the degradation of the coastal and marine ecosystem (Barbosa et al., 2018; Garcés-Ordóñez et al., 2020). This issue has led to serious environmental and socioeconomic problems, ranging from water contamination (Maynard et al., 2021), death of marine animals by ingestion or entanglement (Roman et al., 2020), expenditures on cleanup and the loss of tourism potential (Krelling et al., 2017). Studies have revealed that plastic is the most expressive item in coastal areas in Brazil (Araújo, 2003; Magalhães \& Araújo, 2012; Sassaki et al., 2016; Santos, 2017; Nobre et al., 2018; Andrades et al., 2020; Gonçalves, 2020; Ribeiro et al., 2021). As well as in other parts of the world, (Hengstmann et al., 2017; García-Rivera et al., 2018; Paler et al., 2019; Garcés-Ordóñez et al., 2020; Okuku et al., 2020; Behera et al., 2021; Mugilarasan et al., 2021).

Researches on the environmental perception of marine litter present in coastal areas have been conducted in multiple areas of the world. For example, on the beaches from the south-central Bay of Biscay in Spain, a qualitative (open) questionnaire was applied and data were interpreted on the Likert scale (Rayon-Viña et al., 2018). In contrast to this questionnaire, in the eastern Mediterranean Sea of Israel, an exploratory and qualitative methodology based on a questionnaire was applied, using interviews and surveys (Portman et al., 2019). In Indonesia (Tidung Islands, Jakarta) assessments were performed with the assistance of a questionnaire with descriptive statistical analysis and regression analysis (Hayati et al., 2020). In Chile and Italy, similar researches over the environmental perception were conducted, with both quantitative and qualitative dimensions (González et al., 2021; Forleo \& Romagnoli, 2021), among others. In Brazil, there are several examples of regional studies that portray the perception of beach users about marine pollution by solid waste, as well as to the behavioral changes that are effected in the long term at the social level (Fernandes \& Sansolo, 2013; Freitas et al., 2020; Magalhães \& Araújo, 2012; Nobre, 2019; Timbó et al., 2019). The understanding of the environmental perception of beach users serves as a strategic pre-diagnostic tool to establish guidelines that will guide local managers in beach management proposals and policies (Rodrigues et al., 2012). Given all the complexity of this studied subject, the goal of this research was to evaluate the environmental perception of users regarding the production and disposal of solid waste on the beach of Tamandare - Pernambuco - Brazil. 


\section{Methods and Materials}

\subsection{Study Area}

Tamandaré beach (Figure 1) is located in city of Tamandaré in the state of Pernambuco, northeast Brazil, $\left(08^{\circ} 45^{\prime} 35^{\prime \prime} \mathrm{S}\right.$ and $\left.35^{\circ} 06^{\prime} 45^{\prime \prime} \mathrm{W}\right), 110 \mathrm{~km}$ from the Recife. The municipality population is estimated to be around 23,623 inhabitants (IBGE, 2020). with a significant increase in the number of people during high season, reaching approximately 60 thousand, that is, an increase of about 3.5 times (Araújo and Costa, 2006). Its coast is formed by 12,63 km of beaches and is in the Environmental Protection Area (APA) of Guadalupe and (APA) Costa dos Corais (Firmino, 2006). The delimited study area in the present study is comprised in the center of the municipal capital in a stretch of the Orla de Tamandare known as (Kiosks), a place where concentration of beach users is elevate. The around $25^{\circ} \mathrm{C}$, with higher temperatures between the months of December and March (PIO, 2004).

Figure 1. Location of the municipality of Tamandaré - PE.

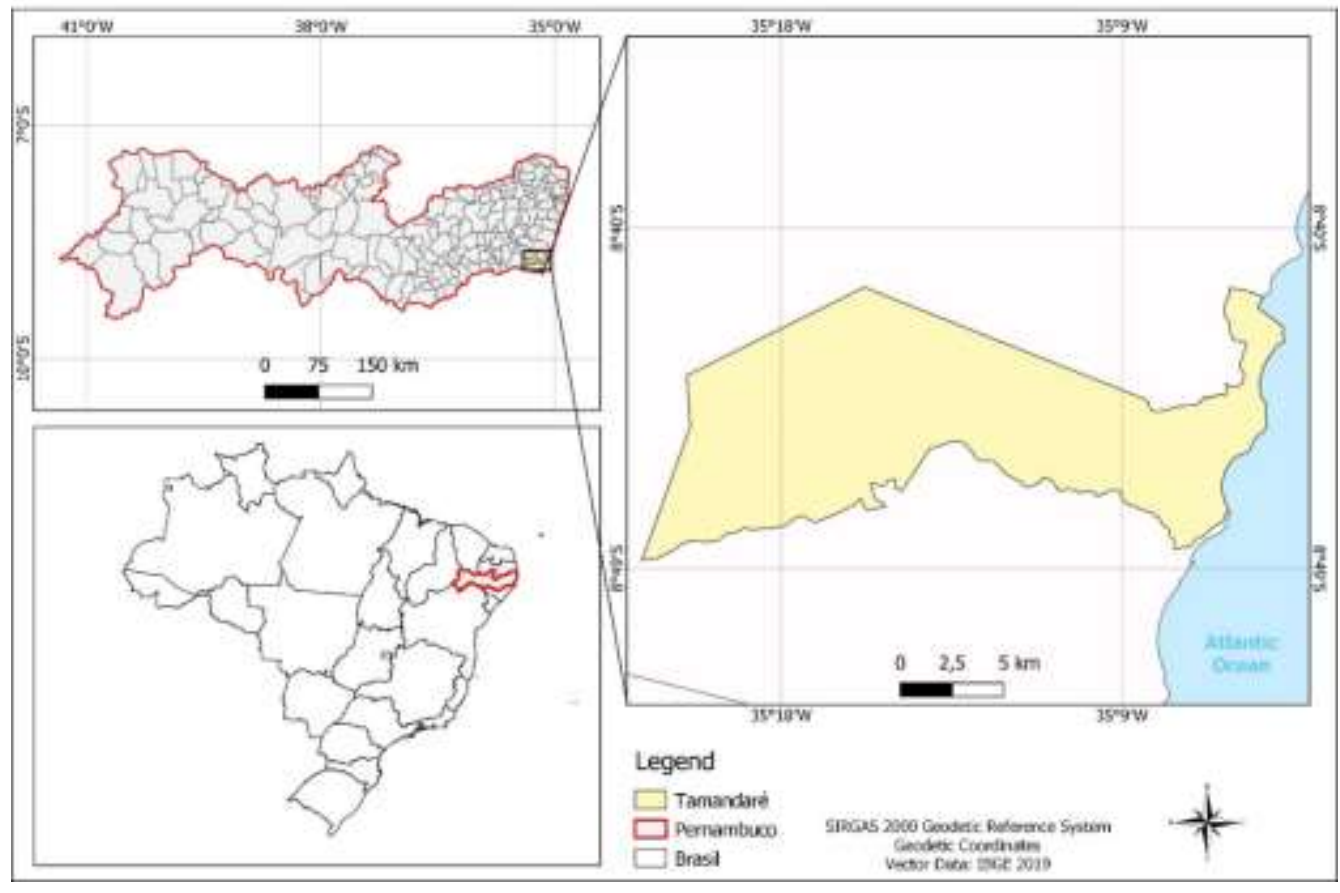

Source: Authors.

\subsection{Social Research}

The study on the environment perception was based on the research of Magalhães e Araújo (2012), which consisted in applying semi-structured interviews based on a qualitative questionnaire divided into two parts (profile analysis and perception/suggestions for mitigating measures). The validated survey was applied, individually on-site, for about 10 minutes per participant. The participants were not identified by name, in order to respect their anonymity. The collected personal data was: gender; age, education level, and family income. The environmental pertinent questions regarding solid waste were analyzed towards the participant's disposal habit, recycling capacity, health potential, level of awareness, view of disturbance and environmental impact, main generating factors, participatory management, and perception of the environmental quality of Tamandaré beach. The survey was conducted in two periods, January (high season) and July (low season) of 2019. A total of 171 questionnaires were applied to tourists, vacationers and to the local population, of which 111 were applied in the high season and 60 in the low season. Participants were randomly approached, and surveys were carried out on weekends around noon, since it has the highest flow-period of people. 


\subsection{Collection sampling protocol}

The residues characterization was performed through a qualitative-quantitative analysis, favoring the expectations of the investigation of the studied phenomenon based on the study of Galgani, et al. (2015). The sampling transect of the collection was an area of $260 \mathrm{~m}$ of extension and $15 \mathrm{~m}$ width, including the sandbank (restinga) vegetation up to low tide line. All the untouched residues and fragments were manually collected during the period of spring tide days, in January and in July. For further analysis, all solid waste on the beach were grouped into categories such as plastic, paper, metal, glass, wood, and cigarette butts. The collection was made with the help of employees of the Tamandaré Environmental Brigade.

\subsection{Statistical Analysis}

The distribution normality of the considered variables was first checked using the Shapiro-Wilk test, followed by an appropriate non-parametric test (Wilcoxon e correlation Kendall-Tau). For the nominal independent variables (month of application and gender), the Wilcoxon non-parametric test was applied, while for the numeric and ordinal independent variables (age and education level) a Kendall-Tau correlation was. Next, the Student's t-test was performed in order to calculate the variance between two different data sets, to compare using the hypothesis test. Finally, the t-test was applied in order to obtain the significance between the averages of the samples collected in the two periods.

\section{Results and discussion}

\subsection{Statistic Analysis}

The normality of the distribution of the considered variables was verified using the Shapiro-Wilk test (Table 1). In this context, accordingly to the p-value, the variables did not present a normal distribution curve, therefore, the Wilcoxon and Kendall-Tau non-parametric tests were used.

Table 1. Shapiro-Wilk normality test on chosen variables. Tamandaré - PE.

\begin{tabular}{lcc}
\hline \multicolumn{1}{c}{ Variables } & W & p-value \\
\hline Age & 0.93522 & $5.644 \mathrm{e}-07$ \\
Education level & 0.89963 & $2.216 \mathrm{e}-09$ \\
Do you usually consume foods and drinks at the beach? & 0.4678 & $<2.2 \mathrm{e}-16$ \\
Do you bring plastic bags for the garbage? & 0.63541 & $<2.2 \mathrm{e}-16$ \\
Waste Disposal Awareness. & 0.72045 & $<2.2 \mathrm{e}-16$ \\
Waste Dispersion Awareness. & 0.39516 & $<2.2 \mathrm{e}-16$ \\
Degree of perception of the types of residual waste & 0.95696 & $4.169 \mathrm{e}-05$ \\
Perception of impairments. & 0.77013 & $4.295 \mathrm{e}-15$ \\
Perception of Impacts. & 0.81618 & $2.11 \mathrm{e}-13$ \\
Perception of triggering fator & 0.85177 & $7.034 \mathrm{e}-12$ \\
Perception of solutions for garbage management, & 0.83627 & $1.433 \mathrm{e}-12$ \\
Classification of beach cleanliness & 0.67296 & $<2.2 \mathrm{e}-16$ \\
\hline
\end{tabular}

Source: Authors.

As none of the variables pointed out to a normal distribution, it was applied the Wilcoxon non-parametric test in the nominal independent variables (month of application and gender) and a Kendall-Tau correlation on the numeric and ordinal independent variables (age and education level). The results showed a 90\% confidence level that the null hypothesis assumes that there is a difference between the genders, whereas the female group has a more sensitive behavior towards the environment than the male group (Table 2). 
Table 2. Wilcoxon non-parametric test and Kendall-Tau correlation on independent variables. Tamandaré - PE.

\begin{tabular}{|c|c|c|c|c|c|c|c|c|}
\hline \multirow{2}{*}{$\begin{array}{c}\text { Variables } \\
\text { (dependents) }\end{array}$} & \multicolumn{2}{|c|}{$\begin{array}{c}\text { Month of } \\
\text { application }\end{array}$} & \multicolumn{2}{|c|}{ Gender } & \multicolumn{2}{|c|}{ Age } & \multicolumn{2}{|c|}{ Level of education } \\
\hline & $\mathbf{W}$ & p-value & $\mathbf{W}$ & p-value & $\mathbf{Z}$ & p-value & $\mathbf{Z}$ & p-value \\
\hline 1. Do you usually consume foods and drinks at the beach? & 3340.50 & 0.97 & 3048.50 & 0.03 & 0.49 & 0.63 & 10.94 & 0.28 \\
\hline 2. Do you bring plastic bags for the garbage? & 3537.00 & 0.44 & 4061.50 & 0.06 & 14.71 & 0.15 & 0.19 & 0.86 \\
\hline 3. Waste Disposal Awareness. & 3345.00 & 0.96 & 4111.00 & 0.04 & 0.54 & 0.60 & 0.80 & 0.25 \\
\hline 4. Waste Dispersion Awareness. & 3896.00 & 0.01 & 3355.50 & 0.26 & 20.74 & 0.04 & 14.65 & 0.15 \\
\hline 5. Degree of perception of the types of residual waste & 4494.50 & 0.01 & 4036.50 & 0.12 & 0.69 & 0.50 & -0.52 & 0.61 \\
\hline 6. Perception of impairments. & 2549.00 & 0.01 & 3882.50 & 0.24 & -0.37 & 0.72 & -0.73 & 0.47 \\
\hline 7. Perception of Impacts. & 4780.00 & 1,04 & 3238.50 & 0.34 & -0.15 & 0.89 & 0.38 & 0.71 \\
\hline 8. Perception of triggering fator & 4817.50 & 4,87 & 3169.50 & 0.24 & 0.17 & 0.88 & -0.95 & 0.35 \\
\hline 9. Perception of solutions for garbage management, & 5227.00 & 1,99 & 3124.00 & 0.19 & -0.43 & 0.67 & -19.61 & 0.05 \\
\hline 10. Classification of beach cleanliness & 3607.50 & 0.25 & 3186.00 & 0.16 & 32.10 & 0.01 & 18.31 & 0.07 \\
\hline
\end{tabular}

Source: Authors.

\subsection{Profile of respondents on Tamandaré beach}

The profile analysis of the interviewees, based on the collected data between the months of January and July, have shown a predominance of the female gender, with a highly participation rate of $59.09 \%$, when compared to the male gender with $40.94 \%$ participation It was verified a higher frequency in the age group from 18 to 25 years old, with a relevant distribution of $30.41 \%, 26$ to 35 years old of $25.73 \%, 36$ to 45 years old of $17.54 \%$ and 46 to 65 years old of $14.04 \%$. Considering the education level, most of the interviewees has high school education (48.54\%), 30.41\% higher education, and $14.04 \%$ elementary school. In the family income, the highest percentual found was $50.29 \%$, which is between 1 and 4 minimum wages. Understanding the point of view of beach users is of great importance, since it shows the indicators that can serve as a basis for possible mitigations of the impacts generated by solid waste (Table 3).

Table 3. Gender, Age, Education and income of respondents. Tamandaré - PE.

\begin{tabular}{lcc}
\hline Gender & January and July & $(\boldsymbol{\%})$ \\
\hline Female & 101 & 59,06 \\
Male & 70 & 40,94 \\
\hline Age range & & \\
\hline 18 to 25 & 52 & 30,41 \\
26 to 35 & 44 & 25,73 \\
36 to 45 & 30 & 17,54 \\
46 to 55 & 24 & 14,04 \\
56 to 65 & 17 & 9,94 \\
66 to 75 & 4 & 2,34 \\
\hline Education level & & \\
\hline Master degree & 1 & 0,58 \\
Specialization & 11 & 6,43 \\
University level & 52 & 30,54 \\
High School & 83 & 48,54 \\
Elementary School & 24 & 14,04 \\
\hline Income & & \\
\hline$\leq 1$ & 26 & 15,20 \\
$\geq 1$ to 4 & 86 & 50,29 \\
$\geq 5$ to 10 & 27 & 15,79 \\
$\geq 11$ to 15 & 8 & 4,68 \\
$\geq 15$ & 1 & 0,58 \\
Unemployed & 23 & 13,45 \\
\hline
\end{tabular}

Source: Authors. 


\subsection{Main sources of solid waste in Tamandaré beach}

The environmental perception of the main source of residues on the Tamandare seashore was similar in both periods 93.22\% e $86.67 \%$, attributing the blame to the users themselves, while in January $4.24 \%$, attributed the fault to the boats and to the tide $2.54 \%$ and $13.33 \%$, respectively (Figure 2).

Figura 2. Main sources of solid waste on the beach Tamandaré-PE.

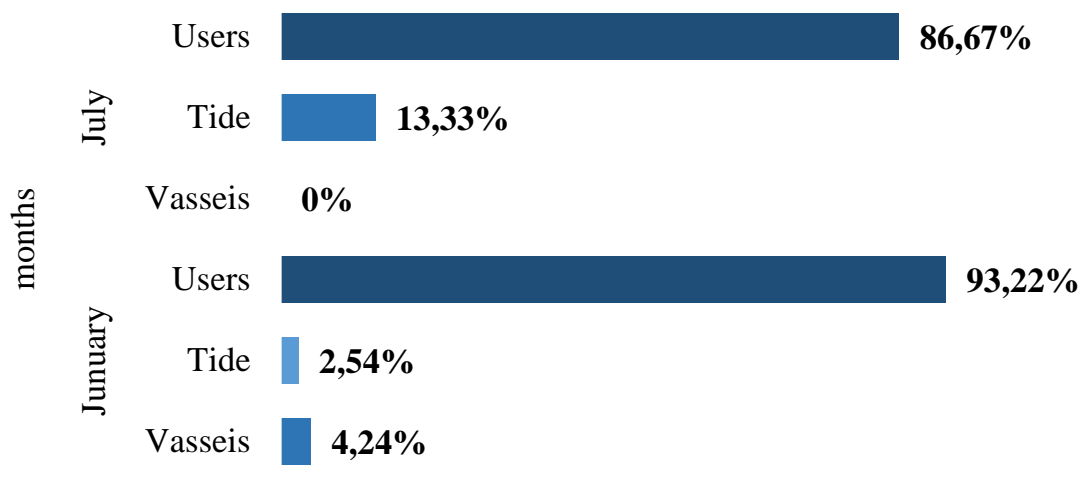

Source: Authors.

Waste sources in coastal areas are not limited to anthropogenic activities. According to the United Nations Environment Programme (UNEP), it was estimated that about $80 \%$ of all solid waste comes from land-based sources and the remaining $20 \%$ comes from sources on the ocean itself, such as debris from ships (Jambeck et al., 2015; Cunha, 2018; Consoli et al., 2020). Regardless of the exact percentages, most of the plastic waste present in the oceans, comes from land-based sources (Magalhaes and Araújo, 2012; Hartley et al., 2018). Once in the oceans, solid waste has a great capacity of dispersion and dissemination by tides, waves, currents, and natural events such as tornadoes, hurricanes, and weather tides, bringing in several environmental and socioeconomic impacts, as well as public finances for local authorities through the increased costs and the loss of potential revenue from tourism, leisure, and recreation activities (PNCLM, 2019).

The United Nations Organization has proposed 17 guidelines for global sustainability, aiming at the well-being of humanity in the "2030 Agenda". In it, Sustainable Development Goal number 14 states that "conservation and sustainable use of the oceans, seas, and marine resources for sustainable development". In its first point, the SDG 14.1, it states that "By 2025, prevent and significantly reduce marine pollution of all types, especially from land-based activities" (UN, 2015).

\subsubsection{Identification of problems generated by the abundance of solid residues in the Tamandaré beach}

Regarding the variety of residues dispersed on the sand strip, it can reach up to $40 \%$ higher amounts during the summer season, consisting mainly of plastics (bottles, bags, caps etc.), aluminum (cans), glass and materials, and been originated from recreational activities on the coast (Galgani et al., 2015). Of the main residues types found on Tamandare seashore, the ones found in abundance during high season were metal, glass, and paper categories, while the wood, styrofoam, and organic matter categories were more abundant in the low season. The items found on the sand strip of the Tamandare shore, corroborates with the study of Scotti et al., (2021) conducted along the Italian coast. The items found with the highest percentage were plastic cups, plates, forks and knives $19.13 \%$, followed by beverages glass bottles $10.90 \%$, groceries and small bags $9.03 \%$, aluminum cans $4.91 \%$, and cigarette butts $4.61 \%$. 
The impacts of presence of litter in the summer months have already been reported in several beaches around the world, such as in Brazil (Silva et al., 2016, Silva et al., 2018), China (Pervez et al., 2020), Chile (Hidalgo-Ruz et al., 2018; Gómez et al., 2020), Taiwan (Chen and Chen, 2020), Argentina (Becherucci et al., 2017) and Spain (Asensio-Montesinos et al., 2019).

Land-based activities related items, such as plastics had the highest representation in both periods, totaling $55.84 \%$ and $60.72 \%$. Among them were: disposable cups $23.55 \%$, plastic bags $22.53 \%$, bottles PET $19.33 \%$, packaging $18.29 \%$, and straws $16.30 \%$. In the wood category $13.59 \%$ and 17.49 , between them popsicle sticks $16.19 \%$, matches $4.72 \%$, barbecue skewers $6.68 \%$ and charcoal $3.48 \%$. In the organic matter category had $11.55 \%$ and $13.53 \%$, coconut $13.25 \%$ and food waste $11.83 \%$. In other categories such as cigarette butts had $5.46 \%$ and $2.64 \%$, glass 6.35 and $0.66 \%$, paper $2.66 \%$ and $1.65 \%$, aluminum cans $3.17 \%$ and $0.99 \%$ and styrofoam $1.40 \%$ and $2.31 \%$. It is noteworthy that respondents were free to mark various options of the most commonly found waste, totaling a percentage of (200\%) (Table 4).

Table 4. Types of solid waste found in the coastal zone of Tamandaré, accordingly to the surveyed.

\begin{tabular}{lcc}
\hline Types of residues & January & July \\
\hline Plastics (cup, bag, bottle, packaging and straw) & $55.84 \%$ & $60.72 \%$ \\
Wood (popsicle sticks, match, barbecue skewers and charcoal) & $13.58 \%$ & $17.49 \%$ \\
Organic matter (coconut and food scraps) & $11.55 \%$ & $13.53 \%$ \\
Cigarette butts & $5.46 \%$ & $2.64 \%$ \\
Glass & $6.35 \%$ & $0.66 \%$ \\
Paper & $2.66 \%$ & $1.65 \%$ \\
Aluminum cans & $3.17 \%$ & $0.99 \%$ \\
Styrofoam & $1.40 \%$ & $2.31 \%$ \\
\hline
\end{tabular}

Source: Authors.

The presence of cigarette butts on beaches is determined by a number of factors, including solar intensity, winds, currents, rivers, and the frequency of beach users. The poor environmental behavior by smokers and inefficient cleaning services are other determinants factors. Regular cleanup (mechanized or manual) by municipal services and episodic events organized by volunteer groups are generally inefficient at removal due to their small size (Araújo and Costa, 2019). Research points to the importance of studies that direct more perspectives of controlling the disposal of cigarette butts in the environment, since they are potentially toxic when discarded in an untimely manner (Ribeiro et al., 2021). Experts have determined that cigarette waste contains more than 7,000 toxic chemicals, which poison not only the atmosphere, but also the soil, seas, and rivers (Rios and Oliveira, 2018). As a preventive measure, some countries, such as the United States, by law, have banned smoking from all beaches in 137 municipalities. Therefore, it is necessary to have restrictive laws and environmental campaigns for smokers (Araújo and Costa, 2019).

\subsubsection{Main impacts caused by solid waste}

In relation to the effects that solid residues can cause, besides all the environmental and health impacts caused, the presence of solid waste on the seashore could have an effect on the economy, since once it is polluted, it impede the return of the beach users (Domínguez Tejo et al., 2018; Turra et al., 2020). This happens since tourism is a factor that generates economic activities and the presence of solid waste on the beaches prevents visitors from coming, making the development of regions or municipalities impossible. Generally, tourism has greater intensity (more tourists) during certain months of the year, coinciding with vacation periods, festivities and seasons (Corluka et al., 2016).

According to Araújo and Costa (2016), beaches can be considered natural playgrounds, offering free spaces for leisure, relaxation, contemplation, and physical activities. However, beaches quality is very important when their social use is considered (Isla, 2013; Botero et al., 2015). One of the most effective solutions for environmental conservation is basic sanitation, whose 
services covers water supply, sanitary sewage, urban cleaning, waste collection and urban drainage, in addition to actions on environmental education (Silva et al., 2016). In the absence of planning, those services can become irregular and inefficient to meet the demand of the population. In the city of Tamandaré, during the vacation season (summer) the population can even triple the size, and the services of electricity, water supply and garbage collection are severely overloaded. The level of perception as to the effects associated to presence of garbage there was a similar effect in both periods for discomfort injuries and. For the discomfort $54.35 \%$ and $57.50 \%$, due to the presence of these debris in the sand strip causing a negative effect on it. For injuries, there was an association with pieces of glass and oysters exposed in the sand $43.48 \%$ and $42.50 \%$. In smaller proportions, it was cited the occurrence of dermatological diseases $2.17 \%$ in the high season, caused by direct contac (Figure 3).

Figure 3. Solid waste related problems at Tamandaré beach.

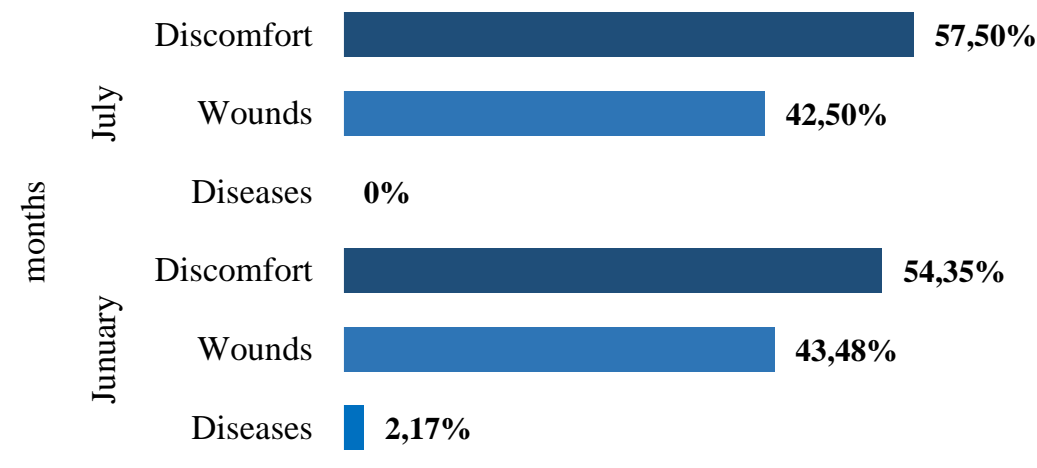

Source: Authors.

\subsubsection{Characterization of the damage that solid waste can cause on the beach}

Solid waste discarded on beaches by its users has affected coastal and marine life in several ways, such as: the ingestion of those materials, that can lead the animal to death due to the accumulation of debris in the gastrointestinal tract causing obstruction; the entanglement in fishing nets, which cause problems in breathing and locomotion, and injuries from the tools used in fishing (Grechinski, 2020; Fernandes et al, 2021). Plastics can also serve as a substrate and vector for dispersal of exotic species, which can considerably influence marine ecosystems (Fernandes et al., 2021). In the social context, the garbage on the seashore can cause for example, lesions and cuts (Campbell et al., 2019 ).

These activities can be described as 14 occasional and punctual meetings with the purpose of collecting the accumulated residues from the environment, that is, its de-pollution. At an international level, the traditional beach clean-up actions take place on the annual World Beach and River Cleanup Day (Menck, 2020). According to Williams et al., (2016), the beach cleanliness is essential to ensure that there is no litter on beaches. This is necessary, avoiding expenses spent for local government administrations on the implementation of cleanups. As an example, the average cost of beach cleaning in Cadiz in southwestern Spain costs 50,376 €/km which is equivalent to an average (329,370.66 Brazilian Real) (Cruz et al., 2020).

One of the main activities that leads to beach marine litter contamination is tourism. In the Tamandaré city, tourism is one of the main economic activities, with many families supported by the local commerce and that are eagerly waiting for the arrival of summer, for the income of revenue. Despite its 12,63 km coastline inside Environmental Protection Area (APA) of Guadalupe and the APA Costa dos Corais, and even with the prohibitive aspects inserted in the national coastal legislation, Tamandaré still has favorable environments for land-based activities, being the target of contamination by solid waste (Firmino, 2006). 
The negative effects totality that the presence of litter can have on the fauna is still unknown, and interviewees were able to perceive the consequences of this irregular disposal, highlighting the death of marine animals, caused by their ingestion. The main cited impacts resulting from the presence of solid waste on Tamandaré shore were the damage to the environment $32.79 \%$ and $47.71 \%$, as well as to health $27.60 \%$ and $28.44 \%$. The interviewees reported they already developed some dermatological disease caused by presence and contact with animal feces, as well as injuring themselves from glass pieces exposed on the sand strip. Other factors were mentioned, such as the disappearance of tourism $25.97 \%$ and $19.27 \%$ and the economic impact $13.64 \%$ and $4.59 \%$ (Figure 4).

Figure 4. Main damages that the presence of solid waste can cause.

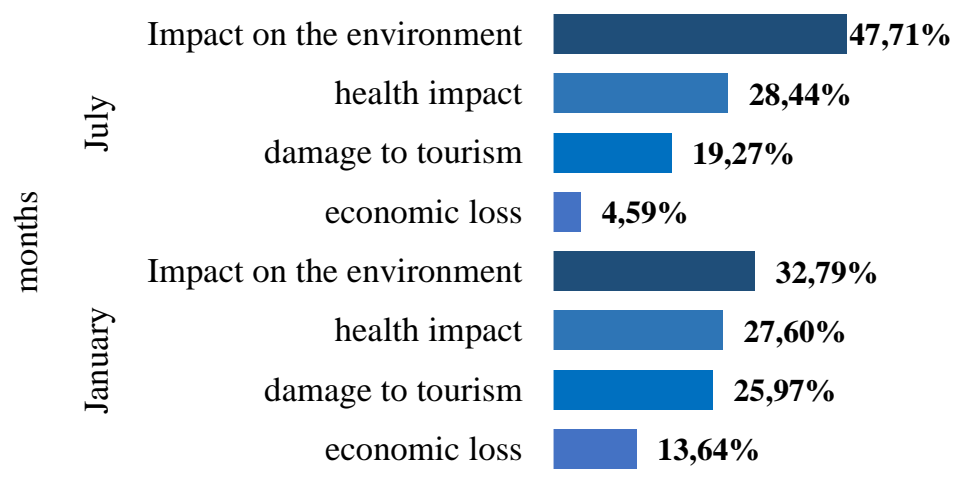

Source: Authors.

\subsubsection{Main causes of irregular disposal of solid waste}

The main factor that leads to coastal contamination and pollution, according to Araújo and Costa (2016), is the uncontrolled increase of the population in those areas, which demands more resources and materials, and higher production and consequent dumping of solid waste in both urban and natural environments. Therefore, the creation of public policies is needed, which are aimed at the well-being of users and the environment. According to Caripuna and Pimentel, (2018), the tourist activity is installed after the improvement of the infrastructure; in which more garbage cans, waste collection and inspections are needed, which can be effective performed with partnerships between owners and the city hall, as well as the waste pickers, who stand out as an important portion to be thought in this system.

In some countries, especially in the European Union, where regions of Germany, Austria, Belgium, Denmark, the Netherlands and Sweden can be highlighted), the effective implementation of MSW management practices have resulted in rates close to $90 \%$ of waste reuse, through a combination of reuse, recycling, composting and waste treatment with energy recovery (through incineration and/or mechanical biological treatment (Eurostat, 2019).

The promenade in Tamandaré has twelve (12) dumpsters for waste storage, from twenty-five (25) kiosks, with the ration of one dumpster to two or three kiosks, depending on the distance. A large accumulation of organic waste (food scraps and coconut shells) was observed, causing a visual impact, and favoring the proliferation of flies, rats and cockroaches.

As for the causes resulting from the irregular disposal of solid waste on the beach, the most comprehensive perception was related to the lack of education of those who produce it, finding an average of $33.83 \%$ and $50.55 \%$. In second place was cited the lack of wastebaskets on the shore, which is insufficient for the city in view of the number of people who frequent the shore, with $27.51 \%$ and $23.08 \%$. Another cause pointed out in third place was the large amount of users with an average of $24.91 \%$ and $16.48 \%$, as well as problems with public collection $13.38 \%$ and $9.89 \%$ (Figure 5). 
Figure 5. Main reasons for the occurrence of solid waste in the Tamandaré beach accordingly to the partitipants perception.

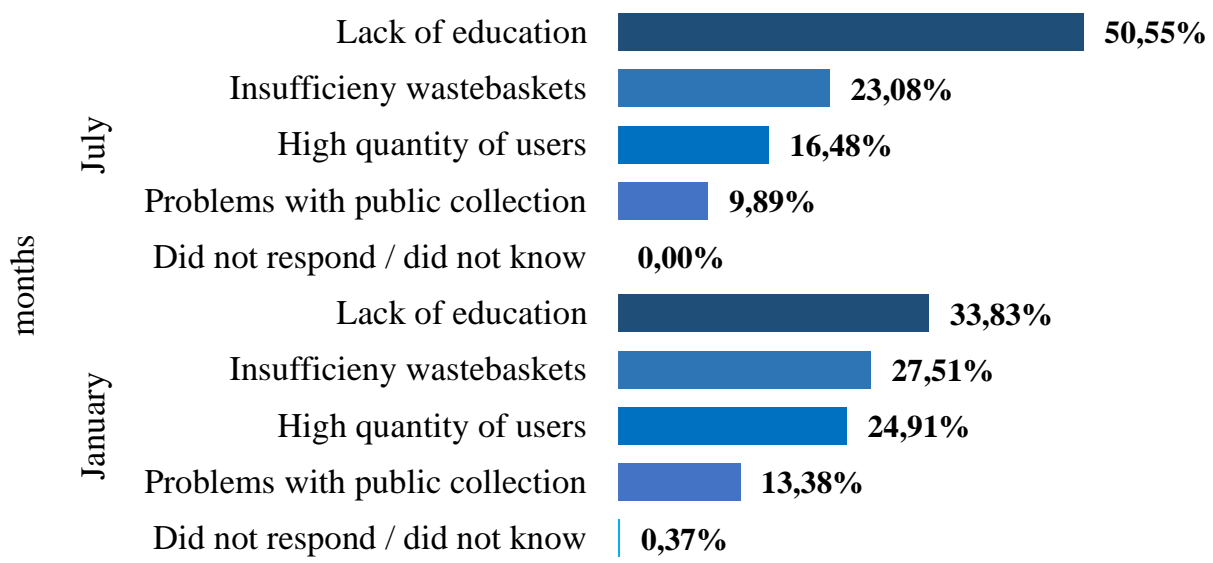

Source: Authors.

Several studies suggested practical or experimental approaches to solid waste to improve awareness on their dispersion problematic. For instance, several studies were performed with adults, young people and children (Marin et al., 2009; Veiga et al., 2016; Löhr et al., 2017; Wyles et al., 2017) (Hartley et al., 2015; Owens, 2018). In addition, surveys based on environmental perception have been used as a pre-diagnostic tool for communities that intend to propose Environmental Education programs, avoiding, as it may occurs, offering a program without adherence with the expectations of the participants (Oliveira et al., 2018). In this sense, Bravo et al., (2018) states that the proper disposal of solid waste implies the awareness of the population and the search for the construction of knowledge, which allows social mobilization and the dissemination of new habits to improve the quality of life. The active participation and the constituted attitudes on environmental education must be inserted in everyday life (home, work, school and city).

Understanding the distribution and dynamics of marine pollution on touristic beaches is essential to find effective solutions accordingly to the local conditions of countries or municipalities (Garcés-Ordóñez et al., 2020). Some projects have been developed by Brazilian universities, such as, for example, the Ecology and Management of Coastal and Estuarine Ecosystems laboratory at UFPE has created the Marine Pollution, Microplastics, and Citizen Science project, which brings an approach to monitoring garbage with the objective of making science between the academic environment and researchers and the participation of society as a possible way to mitigate marine pollution.

As educational and awareness-raising strategies, for the significant reduction of marine pollution and the prevention of ecological and socio-economic impacts, the municipality of Tamandare relies on small actions promoted by the State Environmental Agency (CPRH) in partnership with the local town hall to promote environmental awareness and to contribute with the reduction of environmental impacts generated during the high tourist season.

Among those actions, is the Environment and Leisure Project, working with the environmental education in a playful way with theatrical presentations, recycled material workshops, storytelling, and bags distribution. There is also a project called "Garis Marítimos", a non-governmental action created in 2000 that collects solid waste on the beaches and distributes biodegradable bags between the months of November and February, with a posterior counting and weighing. There is also the Eco-Educar project, which covers the municipalities that are inserted in the conservation unit of APA Costa dos Corais, between Rio Formoso, in the south coast of Pernambuco and Maceió, in the state of Alagoas. This project aims to raise awareness and capacitate children and young people in environmental education through the developed activities. 


\subsubsection{Measures for solutions over the environmental impacts on the coastal area}

The possible solutions proposed by the users of the Tamandaré shore would be to work on the implementation of educational campaigns $26.84 \%$, as well as to increase the number of garbage cans $24.23 \%$ on the sidewalks. Others think that the city should increase the cleaning, especially in the summer, when the beach suffers an increase of population $19.95 \%$. The beach cleaning system is precarious, with only two (2) street cleaners and one tractor for the waste gathering. Even so $16.39 \%$ said that the distribution of plastic bags would be effective as well as the imposition of fines $12.59 \%$, although for this, a constant inspection would be necessary, (Figure 6).

Figure 6. Solution suggestions for reducing the amount of solid waste on the beach.

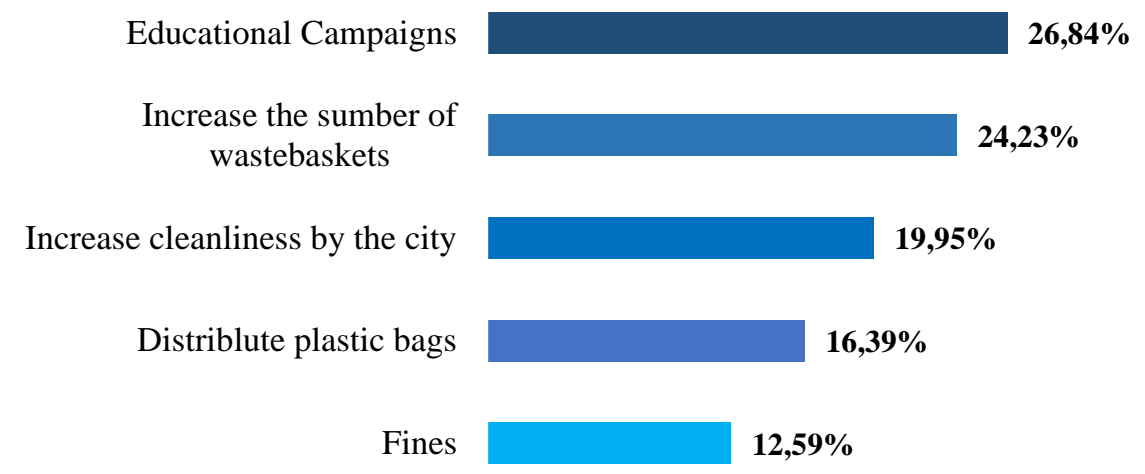

Regarding the use of the plastic bags, it is very clear that this polymer has conquered the planet and its use has become an immediate problem and one of the most significant challenges of the 21 st century for humanity. Plastic is an unequivocal symbol of the crisis of postmodern society (Rangel-Buitrago et al., 2021). The use of plastics have been benefiting the human society in many ways, such as improving consumer health and product durability or reducing $\mathrm{CO}_{2}$ emissions with lightweight materials. However, in recent years plastic has been identified as a widespread and recalcitrant pollutant in aquatic environments. It has been estimated that over 8 million tons of plastic enters the oceans annually, and plastic is now found in all major oceanic gyres, polar seas, and seafloor sediments (Erni-Cassola et al., 2019).

The used of plastic bags as a possible mitigation measure in the reduction of solid waste can be an indicator of pollution. In Tamandare during the high tourist season, a third party company from the city of Caruaru distributes biodegradable bags, in order to promote its brand.

As for the use of bags for waste storage, the research revealed that the female gender $53.47 \%$ has more prudent behavioral attitudes than the male gender $38.57 \%$, where they said they carry plastic bags or reuse the same bags that they carry their food and drinks during recreational activities at the beach. Still others $61.43 \%$ attributed to the male gender and $46.53 \%$ female gender reported not having this habit of carrying.

The urban solid waste management needs to be articulated and the public policies must seek the reduction on the sources, the recycling process and the final disposal. The Tamandaré city regulations that subsidizes urban cleanliness, such as the Solid Waste Management Plan (PGRS), and the Code of Urban Cleaning, instituted on the complementary law $\mathrm{n}^{\circ} 002 / 2010$, besides a recyclable material sorting center with27 integrated collectors, but not offering the minimum working conditions and without the use of personal protection equipment. 


\subsubsection{Foods and beverages consumption by the frequency of beach}

Regarding the food and beverages businesses, beaches are spaces destined for low-cost leisure, accessible to all social classes, becoming the target of an accentuated commercial exploitation, especially from an informal nature (Araújo et al., 2012). Beaches food and beverages businesses can bring social benefits with occupation and revenue to a currently unattended layer of the urban population of coastal urban centers in Brazil, as well as to beach users who have another opportunity to improve the quality of their leisure time by being able to purchase what they need. However, for this social experience of commerce on beaches not to bring unacceptable social and environmental impacts, it would be necessary to order it (Araújo et al., 2012).

Tamandaré beach presents a great variety of commerce, such as support points (kiosks), street vendors, bars and restaurants. Making a correlation between gender and the habit of consumption, it was observed that men use more frequently the types of services offered by the beaches with $90 \%$, while women use less frequently $76.24 \%$. (Figure 7).

Figure 7. Frequency of people who consume food and drinks on the beach by sex. Tamandaré - PE.

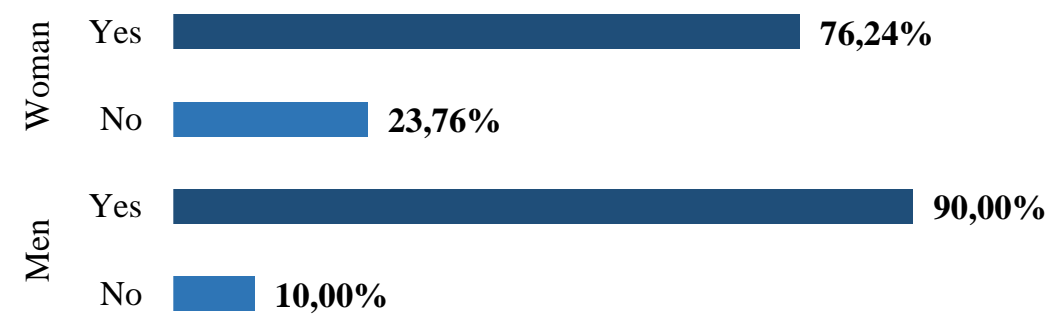

Source: Authors.

\subsubsection{Final destination of solid residues after the consumption by}

As for the correct disposal of solid waste, these actions may be resulted from the absence of knowledge or the lack of awareness. According to Araújo (2003), beach users do not exercise the basic principles of citizenship and treat the public space as an asset that does not belong to them, exempting themselves from the responsibility of keeping it clean. In the analysis of the gender from the interviewees regarding the destination of waste, it was observed that for most of the respondents $65.38 \%$ of the female gender and $57.53 \%$ of male said that they discard it in nearby dumpsters. This attitude of users to utilize local collection structures to dispose of their waste was also shown in the work of Mattos and Bondioli, (2018) at Martins de Sá beach, in São Paulo state. Still, $15.38 \%$ and $28.77 \%$ of participants said they are used to leave it at their own place of consumption (kiosk).

On all the study area's kiosks, wastebaskets were seen near the customer's consumption tables, with some with its own can or others sharing it for two tables. Others said they return home with their waste by, reusing the same bags $13.46 \%$ and $8.22 \%$, while fewer reported putting it in plastic bags and leaving them on the sand for the garbage collectors $4.81 \%$ and $4.11 \%$. In addition, some participants answered that they leave them in the sand, without any caution or guilt, which clearly shows a lack of concern about conserving the natural environment, compromising the coastal and marine ecosystems $0.96 \%$ and $1.37 \%$. The bags left on the sand can be pulled by the tides or even torn by some animals, spreading the residues and favoring the proliferation intrusive organisms, besides the entanglement, toxic effects through the ingestion of plastics, suffocation, starvation, dispersal and rafting of organisms, provision of new habitats, and introduction of invasive species (Thushari \& Senevirathna, 2020) (Figure 8). 
Figure 8. Destination of waste generated on the beach by gender.

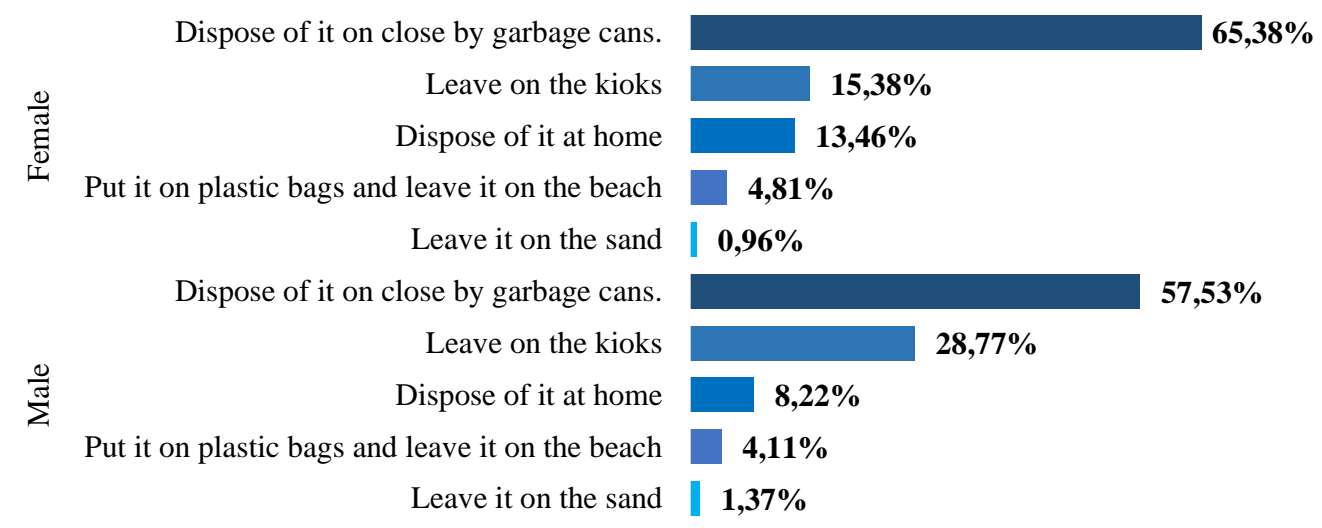

Source: Authors.

\subsubsection{Evaluation of the Tamandaré beach}

Tamandaré beach was classified by the interviewees as clean $73.68 \%$. Others considered it dirty $19.88 \%$. Others said it was very clean $4.68 \%$ and a smaller proportion $1.75 \%$ classified it as very dirty (Figure 9). This analysis corroborates with the work Timbó et al., (2019), which was conducted in Itacoatiara, in the state of Rio de Janeiro, where most of the users considered the beach clean $77 \%$.

Figure 9. Given classification by the Tamandaré beach users.

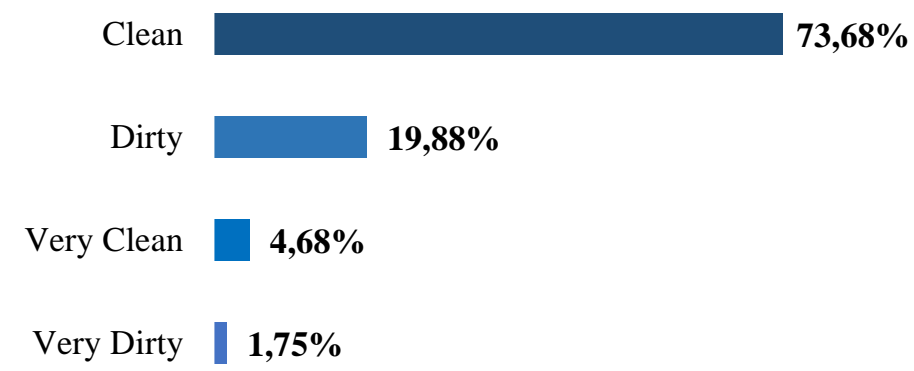

Source: Authors.

\subsubsection{Irregular disposal of solid waste by education level}

There is a relationship between the level of education and background knowledge from people, which means that people with a higher education level are able to have a better understanding and a possible position regarding the global situation and the need to re-think about the consumption patterns (Tramontina \& Carniatto, 2019). This can lead to consequences regarding the irregular disposal of solid waste on the beach. According to Morais et al., (2018), the education level influences the environmental education issue involving the improper disposal of solid urban waste, since low education levels makes it impossible for the people fully know about the environmental impacts caused by waste, and the lack of it can lead people to litter in inappropriate places. For Guimarães and Garcia (2012), besides schooling, people with lower purchasing power are the most responsible for disposing of trash on the beach. This relationship was demonstrated in the work of Santos et al., (2004), where it was found that large amounts of waste are improperly disposed on the beach of Cassino (RS) during the summer months, 
especially in the region frequented by people with lower purchasing power and education. On the other hand, it was nor observed a relationship in the analysis in the context of Tamandaré beach, where the majority of the interviewed users had high school education $59.42 \%$, being $8.70 \%$ incomplete and $50.72 \%$ complete and who also affirmed leaving rubbish at the beach, while $3.92 \%$ and $39.22 \%$ said they had never left it. As for people with higher education level, $11.59 \%$ and $13.04 \%$ answered that they had left it and $6.86 \%$ and $29.41 \%$ that they had not. For elementary school $11.59 \%$ and $4.35 \%$ confirmed having left and $5.88 \%$ and $3.92 \%$ said they had never left. Others $9.80 \%$ and $0.98 \%$ of the post-graduates also said they had never left it. As for the "feelings of guilt", many said they felt guilty for this act, while others said they were not guilty (Table 5).

Table 5. Waste disposal on the beach by scholarity.

\begin{tabular}{lcc}
\hline \multicolumn{1}{c}{ EDUCATION LEVEL } & YES & NO \\
\hline Graduate & 0 & $9.80 \%$ \\
Strictu Sensu Graduate (Academic Master's degree) & 0 & $0.98 \%$ \\
Elementar school (incomplete) & $11.59 \%$ & $5.88 \%$ \\
Elementary school & $4.35 \%$ & $3.92 \%$ \\
College (incomplete) & $11.59 \%$ & $6.86 \%$ \\
College & $13.04 \%$ & $29.41 \%$ \\
High school (incomplete) & $8.70 \%$ & $3.92 \%$ \\
High school & $50.72 \%$ & $39.22 \%$ \\
\hline
\end{tabular}

Source: Authors.

\subsection{Quali-quantitative analysis of the collected solid waste in Tamandaré}

A total of 1789 items were collected on both periods (January and July) of 2019. The residues were collected especially during the weekends (Saturday and Sunday), due to the significant higher number of public, which were attracted by the summer events in Tamandaré, as well as to some specific days during the week (Thursday and Friday) due to the high flow. The quantity of residues collected in the high season is resulting from the increase in the population, which coincides exactly with the school break period. The collection was made with the help of employees of the Tamandaré Environmental Brigade (Table 6).

Table 6. Monthly quantity of residues collected in January and July of 2019.

\begin{tabular}{|c|c|c|c|c|c|c|c|c|c|c|}
\hline \multirow[b]{3}{*}{ Items } & \multirow{2}{*}{\multicolumn{4}{|c|}{ January }} & \multirow{2}{*}{\multicolumn{4}{|c|}{ July }} & \multirow{3}{*}{ Total } & \multirow{3}{*}{$\%$} \\
\hline & & & & & & & & & & \\
\hline & Saturday & Friday & Sunday & Thursday & Friday & Sunday & Sunday & Friday & & \\
\hline Plastic & 205 & 377 & 284 & 200 & 101 & 178 & 140 & 115 & 1.600 & 89,36 \\
\hline Paper & 5 & 7 & 7 & 3 & 2 & 5 & 2 & 1 & 32 & 1.71 \\
\hline Metal & 4 & 4 & 7 & 5 & 1 & 3 & 2 & 2 & 28 & 1.49 \\
\hline Glass & 8 & 12 & 6 & 3 & 2 & 1 & 2 & - & 34 & 1.82 \\
\hline Wood & 13 & 24 & 7 & 1 & - & 2 & 4 & 1 & 52 & 2.83 \\
\hline Cigarette butts & 10 & 15 & 12 & 3 & 3 & 4 & 3 & 2 & 52 & 2.83 \\
\hline Total & 245 & 439 & 323 & 215 & 109 & 193 & 153 & 121 & 1.789 & 100.00 \\
\hline
\end{tabular}

Source: Authors.

Residues were organized on categories according to its nature: plastic, paper, metal, glass, wood and cigarette butts. The Student t test was applied in order to obtain the significance between the data from both collection periods (Galgani, 2015). The results of the test have shown a significant difference for all the categories, except for the item wood (popsicle stick and barbecue stick). The result of the t-test has shown a significant difference for all the categories, except for the wooden item (popsicle stick and barbecue skewer) with results of $\mathrm{p}>0.08$.

The study revealed that plastic was the most representative material in both months of collection, adding up to a total of 1600 items, being (1066 in January) and (534 in July). Therefore, the least found item in the summer was metal, a factor 
explained by the fact that it generates income in a recycling chain in Brazil, so it is collected by individuals of the general public. The result of the analysis, which puts plastic as the most expressive item, is corroborated with the work of Garcés-Ordóñez et al., (2020) conducted in Colombia, Okuku et al., (2020) and Andrades et al., (2020) in Kenya, Behera et al., 2021 and Mugilarasan et al., 2021 in India, among others. Plastics are now known to be ubiquitous in the marine environment, found in the most diverse habitats, from the deepest oceans to intertidal areas (Chiba et al., 2018); All over the world, studies regarding beach residues have helped researchers to document the tendency of pollution in the oceans, serving as good substitute to foreseen the impact of plastics in the marine life (Santos et al., 2016). A broader perspective, which aims to compare beach litter patterns in regional or continental regions, is hampered, however, by the lack of systematic surveys and high variability in methodological approaches. This has lead researchers to seek help from ONGs and non-academic volunteers for important monitoring efforts (Bergmann et al., 2017); as they contribute to the development of strategies to reduce the plastic problem, for example, campaigns and collaborative (Andrades et al., 2020). Marine Pollution, Microplastics, and Citizen Science

\section{Conclusions and Recommendations}

Although a large portion of the Tamandaré beach users have a good level of knowledge about waste disposal, a more sensitive behavior regarding their treatment and regular disposal was observed among women.

Based on the analysis of environmental perception, as a pre-diagnostic tool in the mitigation of impacts generated by the inadequate management of solid waste in coastal areas, it was possible to determine that the main source of waste dispersion at of waste on the Tamandare beach is associated with land-based activities, mainly those arising from tourism. When asked about the impacts of solid waste, the participants said that the environment was the most affected. The lack of attention from beach users may be the reason for the high presence of solid waste, as well as failures in the city's collection system. Participants pointed out some mitigating measures for this issue, such as educational campaigns and the improvement of the infrastructure (increase in the number of garbage cans).

It were collected a total of $89.36 \%$ of plastics among the marine waste, which it was the most found item. There was dissatisfaction with the sanitary conditions of the beach. Therefore, there is an urgent need to reduce the contamination and pollution in beach environments, ensuring the well-being of the population and the preservation of the natural environment. It is recommend for future studies, the development of effective projects on Environmental Education to be applied especially during the high season period. All the evaluation and perception of this survey will be able to mitigate the possible causes of solid waste pollution on Tamandaré beach, with actions in planning and management for environmental sustainability by the collegiate group of the Conselho Municipal de Defesa do Meio Ambiente - CONDEMA. Thus, the implementation of planned actions and the joint collaboration of the parties invoved in the maintenance of the beaches (city hall, government, beach users and kiosk owners) is a priority for a less polluted coastal ecosystem, therefore promoting a vision of the future to the next generations, increasing the quality of life of its inhabitants and generating a balance between society and nature, establishing the principle of sustainability.

\section{References}

Andrades, R., \& Pegado, T., Godoy, B. S., Reis-Filho, J. A. \& Nunes, J. L. S., Grillo, A. C. \& Machado, R. C. et al. (2020). Anthropogenic litter on Brazilian beaches: Baseline, trends and recommendations for future approaches. Marine pollution bulletin, 151, 110842. https://doi.org/10.1016/j.marpolbul.2019.110842

Araújo, M. C. B., \& Costa, M. F. (2016). Praias Urbanas: o que há de errado com elas? Revista Meio Ambiente e Sustentabilidade, 11(05), 51-58.

Araújo, M. C. B. \& Costa, M. F. (2019). A critical review of the issue of cigarette butt pollution in coastal environments. Environmental Research, 172, 137149.

Araújo, M. C. B., \& Silva-Cavalcanti, J. S. (2016). Dieta indigesta: milhares de animais marinhos estão consumindo plásticos. Revista Meio Ambiente e Sustentabilidade, 10(5), 74-81. 
Asensio-Montesinos, F., Anfuso, G., Randerson, P., \& Williams, A. T. (2019). Seasonal comparison of beach litter on Mediterranean coastal sites (Alicante, SE Spain). Ocean \& Coastal Management, 181, 104914. https://doi.org/10.1016/j.ocecoaman.2019.104914

Barboza, L. G. A., Vethaak, A. D., Lavorante, B. R., Lundebye, A. K., \& Guilhermino, L. (2018). Marine microplastic debris: An emerging issue for food security, food safety and human health. Marine pollution bulletin, 133, 336-348. https://doi.org/10.1016/j.marpolbul.2018.05.047

Becherucci, M. E., Rosenthal, A. F., \& Pon, J. P. S. (2017). Marine debris in beaches of the Southwestern Atlantic: An assessment of their abundance and mass at different spatial scales in northern coastal Argentina. Marine pollution bulletin, 119(1), 299-306. https://doi.org/10.1016/j.marpolbul.2017.04.030

Behera, D. P., Kolandhasamy, P., Sigamani, S., Devi, L. P., \& Ibrahim, Y. S. (2021). A preliminary investigation of marine litter pollution along Mandvi beach, Kachchh, Gujarat. Marine pollution bulletin, 165, 112100. https://doi.org/10.1016/j.marpolbul.2021.112100

Bergmann, M., Lutz, B., Tekman, M. B., \& Gutow, L. (2017). Citizen scientists reveal: marine litter pollutes Arctic beaches and affects wild life. Marine Pollution. Bulletin 125, 535-540. https://doi.org/10.1016/j.marpolbul.2017.09.055

Binetti, U., Silburn, B., Russell, J., van Hoytema, N., Meakins, B., Kohler, P., \& Maes, T. (2020). First marine litter survey on beaches in Solomon Islands and Vanuatu, South Pacific: Using OSPAR protocol to inform the development of national action plans to tackle land-based solid waste pollution. Marine Pollution Bulletin, 161, 111827. https://doi.org/10.1016/j.marpolbul.2020.111827

Botero, C., Pereira, C., Tosic, M., \& Manjarrez, G. (2015). Design of an index for monitoring the environmental quality of tourist beaches from a holistic approach. Ocean \& Coastal Management, 108, 65-73. https://doi.org/10.1016/j.ocecoaman.2014.07.017

Bravo, T. L., Peçanha, A. L., Werner, E. T., \& Santos, A. A. O. (2018). Educação ambiental e percepção da implantação de coleta seletiva de lixo urbano em de alegre, es. Revista Gestão \& Sustentabilidade Ambiental, 7(1), 375-396. http://dx.doi.org/10.19177/rgsa.v7e12018375-396

Campbell, J., Bowser, A., \& Fraisl, D., Meloche, M. (2019). Citizen Science and Data Integration for Understanding Marine Litter. Presented at the Data for Good Exchange, New York.

Caripuna, L. A., \& da Silva Pimentel, M. A. (2018). Resíduos sólidos e sustentabilidade ambiental em área costeira. Resíduos, 11(24).

Chen, M. C., \& Chen, T. H. (2020). Spatial and seasonal distribution of microplastics on sandy beaches along the coast of the Hengchun Peninsula, Taiwan. Marine pollution bulletin, 151, 110861. https://doi.org/10.1016/j.marpolbul.2019.110861

Chiba, S., Saito, H., Fletcher, R., Yogi, T., Kayo, M., Miyagi, S., Ogido, M., \& Fujikura, K. (2018). Human footprint in the abyss: 30 year records of deep-sea plastic debris. Marine Policy, 96, 204-212. https://doi.org/10.1016/j.marpol.2018.03.022

Consoli, P., Scotti, G., Romeo, T., Fossi, M. C., Esposito, V., D'Alessandro, M., \& Andaloro, F. (2020). Characterization of seafloor litter on Mediterranean shallow coastal waters: Evidence from Dive Against Debris, a citizen science monitoring approach. Marine pollution bulletin, 150 , 110763. https://doi.org/10.1016/j.marpolbul.2019.110763

Corluka, G., Mikinac, K., \& Milenkovska, A. (2016). Classification of tourist season in costal tourism. UTMS Journal of Economics, 7(1), 71-83.

Cruz, C. J., Muñoz-Perez, J. J., Carrasco-Braganza, M. I., Poullet, P., Lopez-Garcia, P., Contreras, A., \& Silva, R. (2020). Beach cleaning costs. Ocean \& Coastal Management, 188, 105118. https://doi.org/10.1016/j.ocecoaman.2020.105118

Cunha, L. C. D. (2018). Poluição marinha por plásticos: uma questão de direito internacional (Doctoral dissertation).

da Silva, J. L. T., Batista, R. K. S., Neto, A. M. dos. S., \& Landim, M. F. (2016). Projeto praia limpa: avaliando a percepção ambiental dos frequentadores da praia de Atalaia em Aracaju, Se. XIII congresso nacional de meio ambiente de poços de caldas

da Silva, M. L., Castro, R. O., Sales, A. S., \& de Araújo, F. V. (2018). Marine debris on beaches of Arraial do Cabo, RJ, Brazil: An important coastal tourist destination. Marine pollution bulletin, 130, 153-158. https://doi.org/10.1016/j.marpolbul.2018.03.026

da Silva, M. L., Sales, A. S., Martins, S., de Oliveira Castro, R., \& de Araújo, F. V. (2016). The influence of the intensity of use, rainfall and location in the amount of marine debris in four beaches in Niteroi, Brazil: Sossego, Camboinhas, Charitas and Flechas. Marine pollution bulletin, 113(1-2), 36-39. https://doi.org/10.1016/j.marpolbul.2016.10.061

da Silva, M. P. D. C., Ramos, A. P. S. R., da Silva Carneiro, D., dos Santos, E. O., \& do Nascimento, S. P. G. (2016). Estudo dos Resíduos Sólidos na Zona Costeira de Saubara-Ba-um desafio para a gestão ambiental. Seminários Espaços Costeiros.

de Araújo, M. C. B. (2003). Resíduos sólidos em praias do litoral sul de Pernambuco: origens e consequências.

de Araújo, M. C. B., \& Costa, M. F. (2006). Municipal services on tourist beaches: costs and benefits of solid waste collection. Journal of Coastal Research, 22(5 (225)), 1070-1075. https://doi.org/10.2112/03-0069.1

de Araújo, M. C. B., Silva-Cavalcanti, J. S., Vicente-Leal, M. M., \& da Costa, M. F. (2012). Análise do comércio formal e informal na Praia de Boa Viagem, Recife, Pernambuco, Brasil. Revista de Gestão Costeira Integrada-Journal of Integrated Coastal Zone Management, 12(3), 373-388.

de Direitos Humanos, C. (2015). Organização das Nações Unidas. https://brasil.un.org/pt-br/sdgs/14.

de Oliveira, N. R., dos Santos, C. R., \& Turra, A. (2018). Percepção ambiental como subsídio para gestão costeira da Baía do Araçá, Litoral Norte do Estado de São Paulo, Brasil. Desenvolvimento e Meio Ambiente, 44.

Domínguez-Tejo, E., Metternicht, G., Johnston, E.L., \& Hedge, L. (2018). Exploring the social dimension of sandy beaches through predictive modelling. Journal of Environmental Management, 214, 379-407. https://doi.org/10.1016/j.jenvman.2018.03.006 
Erni-Cassola, G., Zadjelovic, V., Gibson, M. I., \& Christie-Oleza, J. A. (2019). Distribution of plastic polymer types in the marine environment; A metaanalysis. Journal of hazardous materials, 369, 691-698. https://doi.org/10.1016/j.jhazmat.2019.02.067

Eurostat. (2019). Waste Generated and Treated in Europe. Office for Official Publications of the European Communities - Environment Statistics, Luxembourg.

Fernandes, L. G., \& Sansolo, D. G. (2013). Percepção ambiental dos moradores da cidade de São Vicente sobre os resíduos sólidos na Praia do Gonzaguinha, SP, Brasil. Revista de Gestão Costeira Integrada-Journal of Integrated Coastal Zone Management, 13(3), 379 -389.

Fernandes, M. E. B., Barcik, D. B., \& Krelling, A. P. (2021). Arte lixo mar: uma poética de sensibilização sobre o lixo marinho. Revista Brasileira De Educação Ambiental (RevBEA), 16(2), 191-211. https://doi.org/10.34024/revbea.2021.v16.11244

Firmino, F. dos S. (2006). Dinâmica do turismo na zona costeira nordestina: Questões conflitantes do desenvolvimento turístico da praia dos Carneiros (Tamandaré/PE). Mestrado em Gestão e Políticas Ambientais, UFPE.

Forleo, M. B., \& Romagnoli, L. (2021). Marine plastic litter: public perceptions and opinions in Italy. Marine Pollution Bulletin, 165, 112160. https://doi.org/10.1016/j.marpolbul.2021.112160

Freitas, J., França, C. L., Fernandes, J. F. F., Furtado, J. A., da Costa Soares, S. H., \& de Jesus, W. B. (2020). Percepção ambiental dos usuários em duas praias do Nordeste do Brasil: a problemática da poluição. Brazilian Journal of Development, 6(6), 33984-34001.

Galgani, F., Hanke, G., \& Maes, T. (2015). Global distribution, composition and abundance of marine litter. In Marine anthropogenic litter (pp. 29-56). Springer, Cham.

Garcés-Ordóñez, O., Espinosa, L. F., Cardoso, R. P., Cardozo, B. B. I., \& Dos Anjos, R. M. (2020). Plastic litter pollution along sandy beaches in the Caribbean and Pacific coast of Colombia. Environmental Pollution, 267, 115495. https://doi.org/10.1016/j.envpol.2020.115495

García-Rivera, S., Lizaso, J. L. S., \& Millán, J. M. B. (2018). Spatial and temporal trends of marine litter in the Spanish Mediterranean seafloor. Marine pollution bulletin, 137, 252-261. https://doi.org/10.1016/j.marpolbul.2018.09.051

Gómez, V., Pozo, K., Nuñez, D., Přibylová, P., Audy, O., Baini, M., \& Klánová, J. (2020). Marine plastic debris in Central Chile: Characterization and abundance of macroplastics and burden of persistent organic pollutants (POPs). Marine Pollution Bulletin, 152, 110881. https://doi.org/10.1016/j.marpolbul.2019.110881

Gonçalves, A. S. (2020). Caracterização e distribuição espaço-temporal dos macrorresíduos sólidos encontrados na praia de Cidreira, RS, Brasil.

González, S. A., Loyola, D., \& Yañez-Navea, K. (2021). Perception of environmental quality in a beach of high social segregation in northern Chile: Importance of social studies for beach conservation. Ocean \& Coastal Management, 207, 105619.

Grechinski, P. (2020). Lixo no mar. Revista Mosaicos: Estudos em Governança, Sustentabilidade e Inovação, 2(1), $30-43$.

Guimarães, G. C., \& Garcia, M. C. D. (2012). Análise Gravimétrica dos Resíduos Sólidos e Perfil dos Usuários Amostrados da Praia da Curva da Jurema (VitóriaEs).

Hartley, B. L., Pahl, S., Veiga, J., Vlachogianni, T., Vasconcelos, L., Maes, T., \& Thompson, R. C. (2018). Exploring public views on marine litter in Europe: perceived causes, consequences and pathways to change. Marine pollution bulletin, 133, 945-955. https://doi.org/10.1016/j.marpolbul.2018.05.061

Hayati, Y., Adrianto, L., Krisanti, M., Pranowo, W. S., \& Kurniawan, F. (2020). Magnitudes and tourist perception of marine debris on small tourism island: Assessment of Tidung Island, Jakarta, Indonesia. Marine Pollution Bulletin, 158, 111393. https://doi.org/10.1016/j.marpolbul.2020.111393

Hengstmann, E., Gräwe, D., Tamminga, M., \& Fischer, E. K. (2017). Marine litter abundance and distribution on beaches on the Isle of Rügen considering the influence of exposition, morphology and recreational activities. Marine pollution bulletin, 115(1-2), 297-306. https://doi.org/10.1016/j.marpolbul.2016.12.026

Hidalgo-Ruz, V., Honorato-Zimmer, D., Gatta-Rosemary, M., Nuñez, P., Hinojosa, I. A., \& Thiel, M. (2018). Spatio-temporal variation of anthropogenic marine debris on Chilean beaches. Marine pollution bulletin, 126, 516-524. https://doi.org/10.1016/j.marpolbul.2017.11.014

IBGE, G. (2020). Fundação Instituto Brasileiro de Geografia e Estatística (IBGE). Available in: https://cidades.ibge.gov.br/brasil/pe/tamandare/panorama. Accessed: May 13, 2021

Isla, F. I. (2013). From touristic villages to coastal cities: The costs of the big step in Buenos Aires. Ocean \& coastal management, 77, 59-65. https://doi.org/10.1016/j.ocecoaman.2012.02.005

Jambeck, J. R., Geyer, R., Wilcox, C., Siegler, T. R., Perryman, M., Andrady, A., \& Law, K. L. (2015). Plastic waste inputs from land into the ocean. Science, 347(6223), 768-771.

Krelling, A. P., Williams, A. T., \& Turra, A. (2017). Differences in perception and reaction of tourist groups to beach marine debris that can influence a loss of tourism revenue in coastal areas. Marine Policy, 85, 87-99. https://doi.org/10.1016/j.marpol.2017.08.021

Liu, J., Liu, N., Zhang, Y., Qu, Z., \& Yu, J. (2019). Evaluation of the non-use value of beach tourism resources: A case study of Qingdao coastal scenic area, China. Ocean \& coastal management, 168, 63-71. https://doi.org/10.1016/j.ocecoaman.2018.10.030

Löhr, A., Savelli, H., Beunen, R., Kalz, M., Ragas, A., \& Van Belleghem, F. (2017). Solutions for global marine litter pollution. Current opinion in environmental sustainability, 28, 90-99. https://doi.org/10.1016/j.cosust.2017.08.009

Magalhães, S. E. F., \& Araújo, M. D. (2012). Lixo marinho na praia de Tamandaré (PE-Brasil): caracterização, análise das fontes e percepção dos usuários da praia sobre o problema. Tropical Oceanography, Recife, 40(2), 193-208. 
Mantelatto, M. C., Póvoa, A. A.; Skinner, L. F., Araújo, F. V. de., \& Creed, J. C. (2020). Marine litter and wood debris as habitat and vector for the range expansion of invasive corals (Tubastraea spp.). Marine Pollution Bulletin, 160, 111659. https://doi.org/10.1016/j.marpolbul.2020.111659

Marin, V., Palmisani, F., Ivaldi, R., Dursi, R., \& Fabiano, M. (2009). Users' perception analysis for sustainable beach management in Italy. Ocean \& Coastal Management, 52(5), 268-277. https://doi.org/10.1016/j.ocecoaman.2009.02.001

Mattos, N. A., \& Bondioli, A. C. V. (2018). Percepção pública e caracterização dos resíduos sólidos como instrumento de apoio para gestão costeira-estudo de caso em Martin de Sá, Caraguatatuba, SP. Revista Gestão \& Sustentabilidade Ambiental, 7(1), 761-775.

Maynard, I. F. N., Bortoluzzi, P. C., Nascimento, L. M., Madi, R. R., Cavalcanti, E. B., Lima, Á. S., \& Marques, M. N. (2021). Analysis of the occurrence of microplastics in beach sand on the Brazilian coast. Science of The Total Environment, 771, 144777. https://doi.org/10.1016/j.scitotenv.2020.144777

Menck, E. V. S. (2020). Um olhar sobre as organizações não-governamentais que realizam ações de educação ambiental focadas em lixo no mar no Brasil.

Morais, E. K. A., de Oliveira, L. J., de Melo, S. A. B. X., de Padua Junior, C. R., \& de Melo, A. X. (2018). Análise da percepção ambiental sobre a geração de resíduos sólidos urbanos dos moradores do bairro Jardim Tarumã no município de Tangará da Serra-MT.

Mugilarasan, M., Karthik, R., Purvaja, R., Robin, R. S., Subbareddy, B., Hariharan, G., \& Ramesh, R. (2021). Spatiotemporal variations in anthropogenic marine litter pollution along the northeast beaches of India. Environmental Pollution, 280, 116954. https://doi.org/10.1016/j.envpol.2021.116954

Nobre, L. R. F. (2019). Percepção ambiental como subsídio para a gestão costeira da Praia da Taíba, Ceará (Brasil).

Okuku, E. O., Kiteresi, L. I., Owato, G., Mwalugha, C., Omire, J., Otieno, K., \& Mulupi, L. (2020). Marine macro-litter composition and distribution along the Kenyan Coast: The first-ever documented study. Marine Pollution Bulletin, 159, 111497. https://doi.org/10.1016/j.marpolbul.2020.111497

Owens, K. A. (2018). Using experiential marine debris education to make an impact: Collecting debris, informing policy makers, and influencing students. Marine pollution bulletin, 127, 804-810. https://doi.org/10.1016/j.marpolbul.2017.10.004

Paler, M. K. O., Malenab, M. C. T., Maralit, J. R., \& Nacorda, H. M. (2019). Plastic waste occurrence on a beach off southwestern Luzon, Philippines. Marine pollution bulletin, 141, 416-419. https://doi.org/10.1016/j.marpolbul.2019.02.006

Pervez, R., Wang, Y., Ali, I., Ali, J., \& Ahmed, S. (2020). The analysis of the accumulation of solid waste debris in the summer season along the Shilaoren Beach Qingdao, China. Regional Studies in Marine Science, 34, 101041. https://doi.org/10.1016/j.rsma.2020.101041

PIO. (2004). Plano de Intervenção na Orla Marítima de Tamandaré. Ministério do Meio Ambiente, Ministério do Planejamento, Orçamento e Gestão.

PNCLM. (2019). Plano Nacional de Combate ao Lixo no Mar. 2019. Brasília- DF. https://www.mma.gov.br/component/k2/item/15428-mma-lan\%C3\%A7aplano-nacional-de combate-ao-lixo-no-mar.html.

Portman, M. E., Pasternak, G., Yotam, Y., Nusbaum, R., \& Behar, D. (2019). Beachgoer participation in prevention of marine litter: Using design for behavior change. Marine pollution bulletin, 144, 1-10. https://doi.org/10.1016/j.marpolbul.2019.04.071

Prevenios, M., Zeri, C., Tsangaris, C., Liubartseva, S., Fakiris, E., \& Papatheodorou, G. (2018). Beach litter dynamics on Mediterranean coasts: Distinguishing sources and pathways. Marine pollution bulletin, 129(2), 448-457. https://doi.org/10.1016/j.marpolbul.2017.10.013

Rangel-Buitrago, N., Mendoza, A. V., Mantilla-Barbosa, E., Arroyo-Olarte, H., Arana, V. A., Trilleras, J., \& Williams, A. T. (2021). Plastic pollution on the Colombian central Caribbean beaches. Marine Pollution Bulletin, 162, 111837. https://doi.org/10.1016/j.marpolbul.2020.111837

Rayon-Viña, F., Miralles, L., Gómez-Agenjo, M., Dopico, E., \& Garcia-Vazquez, E. (2018). Marine litter in south Bay of Biscay: Local differences in beach littering are associated with citizen perception and awareness. Marine pollution bulletin, 131, 727-735. https://doi.org/10.1016/j.marpolbul.2018.04.066

Ribeiro, V. V., Pinto, M. A. S., Mesquita, R. K. B., Moreira, L. B., Costa, M. F., \& Castro, I. B. (2021). Marine litter on a highly urbanized beach at Southeast Brazil: A contribution to the development of litter monitoring programs. Marine pollution bulletin, 163, 111978. https://doi.org/10.1016/j.marpolbul.2021.111978

Rios, D. A. M. \& Oliveira, F. D. S. (2018). Resíduo de cigarro: uma proposta de manejo ambiental. - Instituto Brasileiro de Estudos Ambientais. Rio Grande do Sul.

Rodrigues, M.L., Malheiros, T. F., Fernandes, V., \& Darós, T. D. (2012). A percepção ambiental como instrumento de apoio na gestão e na formulação de políticas públicas ambientais. Saúde e Sociedade, 21, 96-110. https://doi.org/10.1590/S0104-12902012000700009

Rodríguez, Y., Ressurreição, A., \& Pham, C. K. (2020). Socio-economic impacts of marine litter for remote oceanic islands: The case of the Azores. Marine pollution bulletin, 160, 111631. https://doi.org/10.1016/j.marpolbul.2020.111631

Roman, L., Schuyler, Q., Wilcox, C., \& Hardesty, B. D. (2020). Plastic pollution is killing marine megafauna, but how do we prioritize policies to reduce mortality?.Conservation Letters, 12781. https://doi.org/10.1111/conl.12781

Santos, I. R. D., Friedrich, A. C., Fillmann, G., Wallner-Kersanach, M., Schiller, R. V., \& Costa, R. C. (2004). Geração de resíduos sólidos pelos usuários da praia do Cassino, RS, Brasil.

Santos, R.G., Andrades, R., Fardim, L.M., \& Martins, A. S. (2016). Marine debris ingestion and Thayer's law - the importance of plastic color. Environmental Pollution, 214, 585-588. https:// doi.org/10.1016/j.envpol.2016.04.024.

Santos, S. P. (2017). Caracterização e dinâmica do lixo marinho flutuante em praias do litoral da Bahia.

Sanches, V. L., Aguiar, M. R. D. C. M., de Freitas, M. A. V., \& Pacheco, E. B. A. V. (2020). Management of cruise ship-generated solid waste: A review. Marine pollution bulletin, 151, 110785. https://doi.org/10.1016/j.marpolbul.2019.110785 
Research, Society and Development, v. 10, n. 13, e591101319997, 2021

(CC BY 4.0) | ISSN 2525-3409 | DOI: http://dx.doi.org/10.33448/rsd-v10i13.19997

Sassaki, B., Baroni, P. C., da Costa Lucas, A. A., Zeineddine, G. C., Oliveira, K. S., da Gama, L. M., \& Barrella, W. (2016). Composição e caracterização dos resíduos sólidos de diferentes ecossistemas costeiros da Reserva de Desenvolvimento Sustentável da Barra do Una (Peruíbe-SP). Unisanta BioScience, 5(1), 8793.

Scotti, G., Esposito, V., D'Alessandro, M., Panti, C., Vivona, P., Consoli, P., \& Romeo, T. (2021). Seafloor litter along the Italian coastal zone: An integrated approach to identify sources of marine litter. Waste Management, 124, 203-212. https://doi.org/10.1016/j.wasman.2021.01.034

Soto, E. H., Botero, C. M., Milanés, C. B., Rodríguez-Santiago, A., Palacios-Moreno, M., Díaz-Ferguson, E., \& Souza Filho, J. R. (2021). How does the beach ecosystem change without tourists during COVID-19 lockdown? Biological Conservation, 255, 108972. https://doi.org/10.1016/j.biocon.2021.108972

Timbó, M., da Silva, M. L., de Oliveira Castro, R., \& de Araújo, F. V. (2019). Diagnóstico da percepção ambiental dos usuários das praias de Itaipu e Itacoatiara quanto à presença de resíduos sólidos. Revista de Gesão Costeira Integrada / Journal of Integrated Coastal Zone Management, 19(3), 157-166.

Thushari, G. G. N. \& Senevirathna, J. D. M. (2020). Plastic pollution in the marine environment. Heliyon, 6, e04709. enevirathna). https://doi.org/10.1016/j.heliyon.2020.e04709

Tramontina, L. T., \& Carniatto, I. (2019). Influências da Educação Ambiental, do grau de escolaridade e do ambiente de trabalho em práticas ambientais por trabalhadores na indústria. Revista Brasileira de Educação Ambiental (RevBEA), 14(1), 29-48. https://doi.org/10.34024/revbea.2019.v14.2684

Turra, A., Santana, M. F. M., Oliveira, A. de Lima., Barbosa, L., Camargo, R. M., Moreira, F., \& Denadai, M. R. (2020). Lixo nos mares: Do entendimento à solução. Instituto Oceanográfico da Universidade de São Paulo.

Turrell, W. R. (2020). Estimating a regional budget of marine plastic litter in order to advise on marine management measures. Marine pollution bulletin, 150, 110725. https://doi.org/10.1016/j.marpolbul.2019.110725

Vaneeckhaute, C., \& Fazli, A. (2020). Management of ship-generated food waste and sewage on the Baltic Sea: A review. Waste Management, 102, 12-20. https://doi.org/10.1016/j.wasman.2019.10.030

Veiga, J. M., Vlachogianni, T., Pahl, S., Thompson, R. C., Kopke, K., Doyle, T. K., \& Alampei, I. (2016). Enhancing public awareness and promoting coresponsibility for marine litter in Europe: The challenge of MARLISCO. Marine pollution bulletin, 102(2), 309-315. https://doi.org/10.1016/j.marpolbul.2016.01.031

Williams, A. T., Randerson, P., Di Giacomo, C., Anfuso, G., Macias, A., \& Perales, J. A. (2016). Distribution of beach litter along the coastline of Cádiz, Spain. Marine pollution bulletin, 107(1), 77-87. https://doi.org/10.1016/j.marpolbul.2016.04.015

Wyles, K. J., Pahl, S., Holland, M., \& Thompson, R. C. (2017). Can beach cleans do more than clean-up litter? Comparing beach cleans to other coastal activities. Environment and Behavior, 49(5), 509-535. 